\title{
Knowledge, attitude and practice among Ophthalmic Health Care Personnel (HCP) towards COVID-19 pandemic in Nepal: A web-based cross-sectional study
}

\author{
Zahir Ansari ${ }^{1 *}$, Babu Dhanendra Chaurasiya ${ }^{3}$, Sirjana Adhikari ${ }^{2}$, Uday Chandra \\ Prakash $^{4}$, Bikram Adhikari ${ }^{2}$, Sahana Khatoon ${ }^{5}$
}

${ }^{1}$ B.P. Koirala Institute of Health Sciences, Department of Ophthalmology, Dharan, Nepal

2 B.P. Koirala Institute of Health Sciences, School of Public Health and Community Medicine, Dharan, Nepal

${ }^{3}$ Narayani Hospital, Department of Ophthalmology, Birgunj, Nepal

${ }^{4}$ Nobel Medical College, Department of Ophthalmology, Biratnagar, Nepal

${ }^{5}$ Khasyauli Primary Health Care Center, Palpa, Nepal

* Corresponding author

zahirzannat@gmail.com(ZA) 


\begin{abstract}
Background:

Being an added high-risk group, ophthalmic HCP are actively providing emergency eye care services, also enthusiastically participating in prevention and control of the COVID-19 pandemic. Hence, this study aimed to assess the level of knowledge, attitude, and practice (KAP) among ophthalmic HCP towards COVID-19 pandemic.
\end{abstract}

\title{
Methods:
}

A web-based cross-sectional study was conducted during the period of lockdown among ophthalmic HCP including consultant ophthalmologist, resident, optometrist, ophthalmic assistant, nursing staff, and other paramedics of eye care centers in Nepal. The KAP questionnaire was designed and distributed online. Data were analyzed using the Chi-square test, Pearson correlation, and binary logistic regression. All tests were performed at $95 \%$ Confidence Interval (CI) and p-value $<0.05$ was considered statistically significant.

\section{Results:}

Of 694 participants, the majority were male $(59.1 \%)$ from the age group $31-40$ years $(41.5 \%)$ and tertiary eye center $(68.9 \%)$. Among ophthalmic HCP, there were $29.8 \%$ consultants ophthalmologist, $22.6 \%$ residents, $23.3 \%$ optometrist, $15 \%$ ophthalmic assistant, and $9.2 \%$ other ophthalmic paramedics, $11.7 \%$ working as front-liners in COVID-19 centers. Findings showed, $98.1 \%$ had good knowledge, $59.4 \%$ had a positive attitude and only $13.3 \%$ had good practice regarding COVID-19. Binary logistic regression analysis demonstrated the age of $\mathrm{HCP}$ to be a significant determinant of good knowledge (Crude Odds Ratio $(\mathrm{COR})=0.72$, 95\% $\mathrm{CI}=0.62-0.82)$, positive attitude $(\mathrm{COR}=0.92,95 \% \mathrm{CI}=0.90-0.94)$ and good practice $(\mathrm{COR}=1.16,95 \% \mathrm{CI}=1.10-1.21)$. Lower odds of poor practice was seen among junior resident 
$(\mathrm{COR}=0.26,95 \% \mathrm{CI}=0.14-0.47)$ and higher odds of poor practice was seen among HCP with job experience of 5-10 years $(\mathrm{COR}=2.38,95 \% \mathrm{CI}=1.23-4.60)$ towards COVID-19 pandemic.

\section{Conclusion:}

The majority of ophthalmic HCP have good knowledge, insufficient positive attitude, and inadequate evidence-based practice towards the COVID-19 pandemic in Nepal. Hence, this study conclusively recommends to modify existing guidelines and formulate new policies to improve KAP among ophthalmic HCP to effectively control the spread of COVID-19.

Keywords: Knowledge, attitude, practice, KAP, COVID-19, ophthalmic, HCP, Nepal 
medRxiv preprint doi: https://doi.org/10.1101/2020.08.13.20174052; this version posted August 14, 2020. The copyright holder for this preprint

\section{Background}

Mankind is amid a global pandemic at an unprecedented scale due to coronavirus disease 2019 (COVID-19). Initially called then "Severe Acute Respiratory Syndrome Coronavirus-2 (SARS-CoV-2)" when it was first detected by the Center for Disease Control (CDC) China, it was, later designated as COVID-19 by the World Health Organization (WHO) on January 7, $2020[1,2]$.

Dr. Li Wenliang, a Chinese ophthalmologist was among the first to sound an alarm, possible emergence of a new and unusual type of pneumonia. On February 7, 2020, he died of respiratory failure as a complication of the same disease he had tried to warn the world about. Although labeled as a "whistleblower" initially, he was soon regarded as an international hero for his sincere efforts to make the world alert about a danger lurking ahead $[3,4]$.

As compared to other critical care specialists, although the ophthalmologists are less involved in lives saving procedures, they may be the first to see and diagnose new emerging diseases [5].

By January 30, WHO had declared COVID-19 as a Public Health Emergency of International Concern (PHEIC) due to its rapid spread to more than two hundred countries [6]. Then on March 11, 2020, the inevitable announcement roared throughout the planet-WHO announced a first global pandemic in over a hundred years [7]. As of mid-June 2020, there have been more than 7 million confirmed cases and 400,000 mortalities across the globe with still no signs of relief on the horizon [8].

Nepal has the most vulnerable geographical location for this global health crisis. Adding to its owes, is the fact that it is a landlocked country between China-the epicenter of the pandemic; and India-currently a hotspot with the $4^{\text {th }}$ largest "cluster" in the world [8]. The vast porous border that Nepal shares with India have added more salt to the wound as a large number of unorganized migration is occurring daily. The regions of both nations around the 
border has also currently been tagged as "red zones" as more and more cases are being diagnosed every day [9]. It was evident from the beginning when the first COVID-19 case was diagnosed in Nepal that much of the suffering will be due to imported cases. Many also indicated that it will be impossible to escape from COVID-19 and a great preparation will be required if we were to limit the suffering [10]. Till mid-June 2020, Nepal has more than 6000 confirmed cases and 19 mortalities [8].

Due to various restrictions and "lockdown", COVID-19 has affected all services including eye care facility. In Nepal, ophthalmic health care personnel are still actively providing emergency and not allowing much-needed services to falter. At the same time, they have also been enthusiastically participating in the prevention and control of the COVID-19.

In Nepal, especially medical colleges and teaching hospitals that are also providing emergent eye care services, have also been converted into special COVID-19 hospitals/centers. As a result, the ophthalmic health care personnel (HCP) have become directly or indirectly involved in the service to COVID-19 patients.

Owing to the pre-requisites and requirements in an ophthalmic examination, it is almost impossible to maintain a "physical distance" or "time restrictions" as recommended by the WHO or the CDC. The distance between the patient and the ophthalmic HCP is as close as 20 centimeter $(\mathrm{cm})$ in most of the circumstances and the time required for a comprehensive ocular assessment also easily surpasses the guidelines. Contact with the patient is inevitable [11].

Although the risk of transmission is low, acute viral conjunctivitis can be a feature of COVID-19 and tear film (ocular secretions) have the potential for viral transmission [12]. Ophthalmic health care personnel are among high risk compared to other health workers. Due to the frequent exposure to suspected or infected patients, HCP are at serious occupational health risk of COVID-19 [13]. Thus, HCP must have updated knowledge on the source, 
transmission, symptoms, and preventive measures which will help to impose a positive attitude and good practice to assure safety and protection of not only themselves but also of their patients [14].

Various studies have shown that lack of knowledge and misunderstandings among HCP leads to delayed diagnosis, acceleration of the spread, the establishment of a dangerous "chain of transmission" [15]. This will not only lead to infection in HCP but will make them a potential "super spreader". Such missed events have already been documented around the globe [13].

A good knowledge, positive attitude, and evidence-based practice against COVID-19 are very important to fight against this pandemic. Hence, during the period of lockdown when social distancing was a must, this web-based study was designed to assess the level of knowledge, attitude, and practice among ophthalmic health personnel towards COVID-19.

We believe the results will enable us to assess the level of knowledge, attitude, and practice (KAP) among ophthalmic health personnel, which is very essential at the moment. With the help of the results of the study, we can ourselves know where we stand-on in this crisis based on KAP. This can help further design essential plans required for training and interventions, subsequently providing optimum eye care services at the time of pandemic without compromising the protection and safety of the ophthalmic health care personnel and patients. 


\section{Methods}

\section{Study design and duration}

A web-based cross-sectional study was conducted from May $20^{\text {th }}$ to June $9^{\text {th }}, 2020$ during the period of lockdown in Nepal. There was an increasing number of COVID-19 positive cases, as it was not feasible to conduct a population-based study. So, following the norms of the social distancing web-based online data collection method was selected.

\section{Study population, sampling and data collection method}

In the present study, ophthalmic health care personnel (HCP) i.e. ophthalmologist consultant, residents, optometrists, ophthalmic assistant and others (nursing staff, optician, orthoptics) who were directly involved or not involved in COVID-19 pandemic prevention and control, in different eye care health service centers of Nepal during this period of COVID-19 era were the study population.

The sample size was calculated using the Yamane formula. The total sample size was estimated to be 694 with a $5 \%$ margin of error at a $95 \%$ confidence interval. The study population unit was selected using a convenience method of sampling. The survey was started from $20^{\text {th }}$ May and response acceptance was closed on $9^{\text {th }}$ June 2020 after the required sample number achieved. A total of 694 participants were included in the final analysis of this study.

A semi-structured questionnaire was self-designed with the help of a literature review of various studies on COVID-19. The questionnaire was created using the Google-form platform and was distributed via online tools like Emails, Viber, WhatsApp, Facebook/Messenger, Twitter, and Instagram to all participants across the country. Instant online consent was taken from each participant before participating in the survey after a brief introduction to this survey. Pieces of information provided by participants were kept completely confidential and all the data collected in this research were anonymous. All 
medRxiv preprint doi: https://doi.org/10.1101/2020.08.13.20174052; this version posted August 14, 2020. The copyright holder for this preprint

participants' responses were recorded in Google-forms.

\section{Measure}

The questionnaire used in the present study consist of 31 items for assessing Knowledge (10 items), attitude (10 items), and practice (11 items) among ophthalmic health care personnel. The KAP questionnaire was developed based on the study by Ahmed M. Asaad study towards the Middle East Respiratory Syndrome Coronavirus (MERs CoV) [16], the question and answer about COVID-19 in the webpage of WHO [17], COVID-19 ophthalmology practice guidelines by American Academy of Ophthalmology (AAO) and Nepal Ophthalmic society(NOS) [18,19].

Questionnaire pretesting was done by the principal investigator in the presence of a public health expert and an eye specialist, among 10 ophthalmic health care personnel from B.P. Koirala Institute of Health Sciences (BPKIHS), (same sorts of sample that is included in this study) using personal interview method through ZOOM, video-conferencing application. As per results and recommendation questionnaires were further modified to increase its intelligence and validity. Pre-tested data were not included in the final analysis of this study. Questionnaires were divided into four different sections in Google-form. The first section consists of socio-demographic characteristics of study population i.e. age, gender, level of eye care center (i.e. primary, secondary, tertiary and medical college and teaching hospital), location of eye center according to provincial division, position/designation of HCP working in eye center and their job experience (<5years, 5-10 years and $>10$ years), whether eye center having any COVID-19 cases management facility, level of COVID-19 facility (level 1,2,3 or COVID-19 clinic as per MoHP-Ministry of Health and Population) and whether ophthalmic HCP involved in COVID-19 cases management or not (front-liners, second-liners and not involved at all). 
Section two consisted of 10 items of questionnaires assessing knowledge of ophthalmic HCP towards COVID-19 pandemic with multiple choices answering options i.e. "Yes", "No" and "I don't know". The correct response ("Yes") was assigned 1 point while incorrect response ("No" and "I don't know") were assigned zero points. Total maximum scores assigned were 10 with cut off level of greater than or equal to 7 for good knowledge, and less than 7 for poor knowledge.

Section three consisted of 10 items of questionnaires to assess the attitude of ophthalmic HCP towards COVID-19 pandemic with multiple-choice options to answer. Responses were recorded on 5 points likert scale as follows- strongly disagree (1 point), disagree (2 points), undecided/neutral (3 points), agree ( 4 points), and strongly agree (5 points). Total score ranged from 10 to 50 with an overall higher mean score indicates a positive attitude toward COVID-19.

Section four consisted of 11 items of questionnaires to assess the practice of ophthalmic HCP towards COVID-19 pandemic with multiple-choice options to answer ("Yes", "Sometimes" and "No"). The correct response ("Yes") was assigned 1 point while incorrect response ("Sometimes" and "No") were assigned zero points. Total maximum scores were 11, cut off level of greater than equal to 7 for good practice, and less than 7 for poor practice.

\section{Ethics}

Ethical approval was obtained from the Nepal Health Research Council (reference no. 2466). The study questionnaire contained a consent portion that stated purpose, nature of the survey, study objectives, volunteer participation, declaration of confidentiality, and anonymity.

\section{Statistical analysis}

Responses recorded in Google-form were exported to and cleaned in Microsoft Excel 2019 and later imported to Statistical Package for Social Sciences (version-20.0) for statistical 
analysis. The data were summarized in terms of frequency, percentage, mean and standard deviations (SD) and presented in the form of bar diagram-and tables. The confidence interval around the proportion was determined using the Clopper-Pearson method. Chi-square tests were applied to determine the association of knowledge (good vs poor), attitude (positive vs negative), and practice (good vs poor) with socio-demographic characteristics. Pearson correlation was applied to determine the correlation between knowledge, attitude, and practice scores. To find possible determinants of good knowledge and practice, a binary logistic regression analysis was applied. Throughout the study, all tests were two-tailed and carried out at $95 \% \mathrm{CI}$ and p-value less than 0.05 was considered statistically significant. 


\section{Result}

\section{Socio-demographic characteristics of participants}

Table 1 presents the socio-demographic characteristics of the participants.

Table 1: Socio-Demographic Characteristics

\begin{tabular}{cc}
\hline Characteristics $(\mathbf{N}=\mathbf{6 9 4})$ & n $(\%)$ or mean \pm SD \\
\hline Age $($ in years $)$ & $34.6 \pm 6.9$ \\
$20-30$ years & $272(39.2)$ \\
$31-40$ years & $288(41.5)$ \\
$41-50$ years & $122(17.6)$ \\
$51-60$ years & $12(1.7)$
\end{tabular}

\section{Gender}

Male

$410(59.1)$

Female

284 (40.9)

Ophthalmic health care personnel(HCP)

Consultant

207 (29.8)

Junior resident

157 (22.6)

Optometrist

$162(23.3)$

Ophthalmic assistant

$104(15.0)$

Others*

\section{Province}

Province 1

$224(32.3)$

Province 2

119 (17.1)

Bagmati

175 (25.2)

Gandaki

$45(6.5)$

Province 5

97 (14.0)

Karnali

Sudur Paschim

19 (2.7)

\section{Level of the eye center}

Primary

Secondary

62 (8.9)

Tertiary

478 (68.9) 
Job experience

$<5$ years

5-10 years

$158(22.8)$

$>10$ years

$46(6.6)$

\section{COVID-19 center}

Yes

No

Level of COVID-19 center $(\mathrm{N}=163)$

Level 1

Level 2

Level 3

COVID-19 clinic

Involvement in COVID-19 cases management

Frontliners

Second liners

None

$508(73.2)$

n: frequency, \%: percentage, SD: Standard Deviation others* includes nursing staff, optician and orthoptics

\section{Knowledge, attitude and practice}

Figures below showed responses of ophthalmic health care personnel about questionnaires about knowledge, attitude and practice towards COVID-19 pandemic(figure 1,2 and 3)

Figure 1: Knowledge of participated ophthalmic HCP towards COVID-19 pandemic.

Figure 2: Attitude among participated ophthalmic HCP towards COVID-19 pandemic.

Figure 3: Practice of participated ophthalmic HCP towards COVID-19 pandemic.

In this study, the majority of respondents $98.1 \%$ (95\% CI: 96.8-99.0) had good knowledge regarding COVID-19. Among all participants, 59.4\% (95\% CI: 55.6-63.0) participants had a 
medRxiv preprint doi: https://doi.org/10.1101/2020.08.13.20174052; this version posted August 14, 2020. The copyright holder for this preprint (which was not certified by peer review) is the author/funder, who has granted medRxiv a license to display the preprint in perpetuity.

It is made available under a CC-BY-NC-ND 4.0 International license .

positive attitude towards COVID-19. To our most surprise, only $13.3 \%$ (95\% CI: $10.8-16.0$ )

following good practice regarding COVID-19 pandemic as shown in figure 4.

\section{Figure 4: KAP among ophthalmic HCP towards COVID-19}

\section{Factors associated with KAP}

Table 2 and 3 presents the factors associated with knowledge, attitude and practice among ophthalmic HCP. Knowledge was significantly associated with age $(\mathrm{p}=0.019)$, designation HCP ( $p<0.001)$, involvement in COVID-19 case management $(\mathrm{p}<0.001)$ and association with COVID-19 center $(\mathrm{p}=0.001)$. Attitude towards COVID-19 was significantly associated with age $(\mathrm{p}<0.001)$, designation HCP $(\mathrm{p}<0.001)$, job experience $(\mathrm{p}=0.005)$, level of eye center $(\mathrm{p}<0.001)$ and involvement in COVID-19 case management $(\mathrm{p}<0.001)$. Practice was significantly associated with age $(\mathrm{p}<0.001)$, designation $\mathrm{HCP}(\mathrm{p}<0.001)$, job experience $(\mathrm{p}=0.029)$, level of eye center $(\mathrm{p}<0.001)$, involvement in COVID-19 case management $(\mathrm{p}<0.001)$ and affiliation to COVID-19 center $(\mathrm{p}=0.001)$.

Table 2: Association of KAP with different factors

\begin{tabular}{|c|c|c|c|c|c|c|c|c|c|}
\hline \multirow{2}{*}{$\begin{array}{c}\text { Characteristics } \\
\qquad \mathrm{N}=694\end{array}$} & \multicolumn{3}{|c|}{ Knowledge* } & \multicolumn{3}{|c|}{ Attitude ${ }^{* *}$} & \multicolumn{3}{|c|}{ Practice**** } \\
\hline & Good & Poor & $\mathbf{P}$ & Positive & Negative & $\mathbf{p}$ & Good & Poor & $\mathbf{P}$ \\
\hline \multicolumn{10}{|l|}{ Age } \\
\hline 20-30 years & $262(96.3)$ & $10(3.7)$ & \multirow{3}{*}{0.019} & $135(49.6)$ & $137(50.4)$ & \multirow{3}{*}{$<0.001$} & $57(21)$ & $215(79)$ & \multirow{3}{*}{$<0.001$} \\
\hline $31-40$ years & 286(99.3) & $2(0.7)$ & & $170(59)$ & $118(41)$ & & $29(10.1)$ & 259(89.9) & \\
\hline$>40$ years & 133(99.3) & $1(0.7)$ & & 107(79.9) & $27(20.1)$ & & $6(4.5)$ & $128(95.5)$ & \\
\hline \multicolumn{10}{|l|}{ Gender } \\
\hline Male & 402(98) & $8(2)$ & \multirow{2}{*}{0.855} & $247(60.2)$ & $163(39.8)$ & \multirow{2}{*}{0.803} & $57(13.9)$ & $353(86.1)$ & \multirow{2}{*}{0.547} \\
\hline Female & 279(98.2) & $5(1.8)$ & & $165(58.1)$ & $119(41.9)$ & & $35(12.3)$ & $249(87.7)$ & \\
\hline \multicolumn{10}{|l|}{ Designation HCP } \\
\hline Consultant & 206(99.5) & $1(0.5)$ & \multirow{5}{*}{$<0.001$} & $158(76.3)$ & $49(23.7)$ & \multirow{5}{*}{$<0.001$} & $19(9.2)$ & $188(90.8)$ & \multirow{5}{*}{$<0.001$} \\
\hline Junior resident & 156(99.4) & $1(0.6)$ & & $93.2(71.3)$ & $63.8(28.7)$ & & $44(28)$ & $113(72)$ & \\
\hline Optometrist & 159.0(99.4) & $3.0(0.6)$ & & $135(83.3)$ & $27(16.7)$ & & $12(7.4)$ & $150(92.6)$ & \\
\hline $\begin{array}{l}\text { Ophthalmic } \\
\text { assistant }\end{array}$ & $97(93.3)$ & $7(6.7)$ & & $4(3.8)$ & $100(96.2)$ & & $10(9.6)$ & $94(90.4)$ & \\
\hline Others & $61(95.3)$ & $3(4.7)$ & & $3(4.7)$ & $61(95.3)$ & & $7(10.9)$ & $57(89.1)$ & \\
\hline \multicolumn{10}{|l|}{ Job experience } \\
\hline$<5 \mathrm{yrs}$ & $479(97.8)$ & $11(2.2)$ & & $272(55.5)$ & $218(44.5)$ & \multirow{3}{*}{0.005} & $74(15.1)$ & $416(84.9)$ & \multirow{3}{*}{0.029} \\
\hline $5-10$ yrs & $158(100)$ & 0 & - & $110(69.6 \%)$ & $48(30.4 \%)$ & & $11(7 \%)$ & $147(93 \%)$ & \\
\hline$>10 \mathrm{yrs}$ & $44(95.7 \%)$ & $2(4.3 \%)$ & & $30(65.2 \%)$ & $16(34.8 \%)$ & & $7(15.2 \%)$ & $39(84.8 \%)$ & \\
\hline
\end{tabular}




\begin{tabular}{|c|c|c|c|c|c|c|c|c|c|}
\hline $\begin{array}{l}\text { Province } \\
\text { Province } 1\end{array}$ & $220(98.2)$ & $4(1.8)$ & & $98(43.8)$ & $126(56.2)$ & & $27(12.1)$ & 197(87.9) & \\
\hline Province 2 & $114(95.80$ & $5(4.2)$ & & $81(68.1)$ & $38(31.9)$ & & $10(8.4)$ & 109(91.6) & \\
\hline Bagmati & 172(98.3) & $3(1.7)$ & & $118(67.4)$ & $57(32.6)$ & & $41(23.4)$ & $134(76.6)$ & \\
\hline Gandaki & $44(97.8)$ & $1(1.7)$ & - & $25(55.6)$ & $20(44.4)$ & $<0.001$ & $9(20)$ & $36(80)$ & $<0.001$ \\
\hline Province 5 & $97(100)$ & 0 & & $65(67)$ & $32(33)$ & & $5(5.2)$ & $92(94.8)$ & \\
\hline Karnali & $15(100)$ & 0 & & $10(66.7)$ & $5(33.3)$ & & 0 & $15(100)$ & \\
\hline Sudur Paschim & $19(100)$ & 0 & & $15(78.9)$ & $4(21.1)$ & & 0 & $19(100)$ & \\
\hline $\begin{array}{l}\text { Level of eye } \\
\text { center }\end{array}$ & & & & & & & & & \\
\hline Primary & $23(92)$ & $2(8)$ & & $5(20)$ & $20(80)$ & & $9(36)$ & $16(64)$ & \\
\hline Secondary & $62(100)$ & 0 & & $22(35.5)$ & $40(64.5)$ & & $9(14.5)$ & $53(85.5)$ & \\
\hline Tertiary & 470(98.3) & $8(1.7)$ & - & $312(65.3)$ & $166(34.7)$ & $<0.001$ & $37(7.7)$ & $441(85.5)$ & $<0.001$ \\
\hline $\begin{array}{l}\text { Medical college } \\
\text { and teaching } \\
\text { hospital } \\
\text { Involvement in }\end{array}$ & $\begin{array}{l}\text { 126(97.7) } \\
\text { VID-19 case }\end{array}$ & $\begin{array}{l}3(2.3) \\
\text { nagemer }\end{array}$ & & $73(56.6)$ & $56(43.4)$ & & $37(28.7)$ & $92(71.3)$ & \\
\hline Frontliners & $75(92.6)$ & $6(7.4)$ & & $36(44.5)$ & $45(55.6)$ & & $49(60.5)$ & $32(39.5)$ & \\
\hline Second liners & 103(98.1) & $2(1.9)$ & $<0.001$ & $50(47.6)$ & $55(52.4)$ & $<0.001$ & $19(18.1)$ & $86(81.9)$ & $<0.001$ \\
\hline $\begin{array}{l}\text { None } \\
\text { COVID-19 } \\
\text { center }\end{array}$ & 503(99) & $5(1)$ & & $326(64.2)$ & $182(35.8)$ & & $24(4.7)$ & $484(95.3)$ & \\
\hline Yes & 155(95.1) & $8(4.9)$ & & $92(56.4)$ & $71(43.6)$ & & $57(35)$ & $106(65)$ & \\
\hline No & $526(99.1)$ & $5(0.9)$ & 0.01 & $320(60.3)$ & 211(39.7) & 0.385 & $35(6.6)$ & 496(93.4) & 0.001 \\
\hline
\end{tabular}

n: frequency, \%: percentage

*Knowledge: Total maximum scores assigned were 10, cut off level of greater than or equal to 7 for good knowledge, and less than 7 for poor knowledge.

**Attitude: Total score ranges from 10-50, with an overall higher mean score indicates a positive attitude toward COVID-19.

****Practice: Total maximum scores were 11, cut off level of greater than equal to 7 for good practice, and less than 7 for poor practice.

Note: A p value of less than 0.05 considered significant. Bold values showing significant association. 
Binary logistic regression analysis (Table 3) revealed that odds of having poor knowledge and poor attitude decrease by $0.72(0.62-0.82)$ and $0.92(0.90-0.94)$ times respectively, and odds of poor practice increase by $1.16(1.10-1.21)$ times, with the increment of one year age. The odds of having poor knowledge among front-liners were 8.0 (2.40-27.03) times more compared to those who were not involved. The odds of poor practice among front-liners and second-liners were $0.03(0.02-0.06)$ and $0.22(0.12-0.43)$ times less, and odds of poor attitude among front-liners and second-liners were 2.24 (1.40-3.60) and 1.97 (1.29-3.01) times more compared to those who were not involved.

The odds of having poor practice and poor attitude among participants with experience of 510 years was $0.54(0.37-0.80)$ times less and $2.38(1.23-4.60)$ times more respectively compared to participants of experience of fewer than five years.

Table 3: Logistic regression analysis for factors associated with knowledge, attitude and practice towards COVID-19

\begin{tabular}{|c|c|c|c|c|c|c|}
\hline \multirow[t]{2}{*}{ Variables $(\mathrm{N}=694)$} & \multicolumn{2}{|l|}{ Knowledge } & \multicolumn{2}{|l|}{ Attitude } & \multicolumn{2}{|c|}{ Practice } \\
\hline & $\operatorname{COR}(95 \% \mathrm{CI})$ & $\mathrm{P}$ & $\operatorname{COR}(95 \% \mathrm{CI})$ & $\mathrm{P}$ & $\operatorname{COR}(95 \% \mathrm{CI})$ & $\mathrm{P}$ \\
\hline$\overline{\text { Age }}$ & $0.72(0.62-0.82)$ & $<0.001$ & $0.92(0.90-0.94)$ & $<0.001$ & $1.16(1.10-1.21)$ & $<0.001$ \\
\hline \multicolumn{7}{|l|}{ Gender } \\
\hline Male & $1.11(0.36-3.43)$ & 0.856 & $0.92(0.67-1.25)$ & 0.572 & $0.87(0.55-1.37)$ & 0.547 \\
\hline Female(ref) & 1 & & 1 & & 1 & \\
\hline \multicolumn{7}{|l|}{ Designation HCP } \\
\hline Consultant (ref) & 1 & & 1 & & 1 & \\
\hline Junior resident & $1.32(0.082-21.277)$ & 0.845 & $1.30(0.81-2.07)$ & 0.282 & $0.26(0.14-.47)$ & $<0.001$ \\
\hline Optometrist & $1.280(0.079-20.613)$ & 0.862 & $0.645(0.38-1.09)$ & 0.100 & $1.26(0.59-2.69)$ & 0.543 \\
\hline Ophthalmic assistant & $14.87(1.80-122.51)$ & 0.012 & $80.61(28.22-230.25)$ & $<0.001$ & $0.95(0.43-2.12)$ & 0.901 \\
\hline Others & $10.13(1.04-99.16)$ & 0.047 & $65.57(19.70-218.24$ & $<0.001$ & $0.82(0.33-2.06)$ & 0.823 \\
\hline \multicolumn{7}{|l|}{ Job experience } \\
\hline$<5$ years $($ ref $)$ & 1 & & 1 & & 1 & \\
\hline 5-10 years & 0 & 0.996 & $0.54(0.37-0.80)$ & 0.002 & $2.38(1.23-4.60)$ & 0.010 \\
\hline
\end{tabular}


medRxiv preprint doi: https://doi.org/10.1101/2020.08.13.20174052; this version posted August 14, 2020. The copyright holder for this preprint (which was not certified by peer review) is the author/funder, who has granted medRxiv a license to display the preprint in perpetuity.

It is made available under a CC-BY-NC-ND 4.0 International license.

$>10$ years

1.98(0.43-9.21)

0.384

$0.67(0.35-1.25)$

0.207

$0.99(0.43-2.30)$

0.983

Level of the eye center

Primary

Secondary

Tertiary

$3.65(0.58-23.08)$

0

0.72(0.19-2.73

Medical college and

teaching hospital (ref)

Involvement in COVID-19 case management

Front-liners

Second-liners

8.0(2.40-27.03)

$1.95(0.37-10.21)$

None(ref)

COVID-19 center

Yes

$5.43(1.75-16.84)$

No (ref)

COR: Crude Odds Ratio; CI: Confidence Interval

Note: A p value of less than 0.05 is considered significant. Bold value indicates significantly associated factors.

Pearson correlation tests revealed a statistically significant moderate positive correlation between knowledge-attitude $(\mathrm{r}=0.609, \mathrm{p}<0.001)$ and weak positive correlation between knowledge-practice $(\mathrm{r}=0.300, \mathrm{p}<0.001)$, and attitude-practice $(\mathrm{r}=0.124, \mathrm{p}=0.001)$.

\section{Table 3: Correlation between KAP scores}

\begin{tabular}{lcc}
\hline Variables & Correlation coefficient $(\mathbf{r})$ & p- value \\
\hline Knowledge-attitude & $0.609 * *$ & $<0.001$ \\
Knowledge-practice & $0.300 * *$ & $<0.001$ \\
Attitude-practice & $0.124 * *$ & 0.001 \\
\hline
\end{tabular}

** Correlation is significant at the 0.05 level (2-tailed). 


\section{Discussion}

To the best of our knowledge, this is the first study that has been conducted aimed to determine the level of knowledge, attitude, and practice among ophthalmic health care personnel in Nepal towards the COVID-19 pandemic. Even we assumed, this might be the first KAP study that has been done among ophthalmic health care personnel even across the world about COVID-19 pandemic.

In the present study, $98.1 \%$ have good knowledge towards COVID-19 pandemic in Nepal, our findings were consistent to the studies conducted by Hussain et al. [20], Richa et al. [21] in Chitwan (Nepal), Saqlain et al. [22] in Pakistan, Zhou et al. [23] in China and Giao et al. [24] in Vietnam which reported good knowledge among $82.2 \%, 93.2 \%, 89 \%$, and $88.4 \%$ participants respectively towards COVID-19. In contrast to our findings, a study conducted among nurses reported that $56.5 \%$ of respondents had sufficient knowledge regarding the transmission, symptoms, and treatment of COVID-19 [14]. This awareness has got more significance in the current scenario when no vaccine has been available till now and various researches are ongoing. So all ophthalmic and non-ophthalmic HCP must be aware of all the updates and should take precautions regarding treatment and prevention of COVID-19 infection [23].

In this study, $1.9 \%$ had poor knowledge regarding COVID-19, this mostly accounted because of the incorrect answer of questions regarding the risk of irreversible maculopathy at the higher doses of chloroquine and hydroxychloroquine for short periods (30.8\% incorrect responses) and use of FDA issued remdesivir - an emergency authorization for the treatment of suspected or laboratory-confirmed COVID-19 (28.8\% incorrect responses). The role of chloroquine and hydroxychloroquine in COVID-19 is still under investigations, many trials are going on all over the world as per WHO [25]. Since these drugs can cause ocular toxicity but its use for small duration has not been extensively studied, hence it is controversial. Also, 
remdesivir [26] being a new promising and emerging drug, found effective against COVID19. Hence, public health practitioners must be updated on the most promising potential therapeutic drugs that are under investigation. These might be reasons behind the incorrect response to these questions.

Hussain et al. (70-80\%), Richa et al. (90.93\%), Saqlain et al. (60-80\%) and Giao et al. (more than $80 \%$ ) reported positive attitude among the higher proportion of participants [20-22,24] compared to present study which reported positive attitude among $59.4 \%$. This might be due to good knowledge which is directly proportionate to a positive attitude towards COVID-19. Similarly, in a KAP study related to Ebola virus disease by Iliyasu et al. a negative attitude was related to a lack of knowledge about the use of PPE and the shortage of PPE [27]. At present context in our country, there is both lack of knowledge about the use of PPE as well as a shortage of PPE. Other causes might be lack of specific treatment and vaccine for COVID-19, incompetency of central government, lack of overall scientific policies towards combating COVID-19, lack of preparedness of hospitals of our country, lack of adequate testing for COVID-19, lack of work incentives, insurance policy, job security, provision for families of HCWs, appropriate training, lack of skilled manpower, provision of treatment if tested positive and long and hectic duty hours.

In this study, $13.3 \%$ had good practice regarding COVID-19 pandemic which was much lower compared to Hussain et al (more than $80 \%$ ), Richa et al. (83.57\%), Saqlain et al( $88.7 \%$ ), and Albarrak et al(more than 80\%) [20-22,28]. This might be due to a lack of active participation of ophthalmic HCP in the management of COVID-19 at the time of the pandemic.

Richa et al. and Saqlain et al. reported a significant association between age and good knowledge $[21,22]$ in agreement to present study but Giao et al. failed to find a significant association between knowledge and age [24]. Similar to this study, Richa et al. reported a 
significant association between age and positive attitude [21], and in contrast Saqlain et al. and Albarrak et al. failed to find a significant association [22,28].

There was no statistically significant difference of knowledge, attitude, and practice among males and females which was similar to the findings of Saqlain et al. and Giao et al. [22,24], and was different from Richa et al. and Albarrak et al. [21,28]

In this study, there was no significant difference of knowledge about COVID-19 according to their position and designation of ophthalmic HCP in accordance with Saqlain et al, and contrast to Richa et al, Giao et al, and Albarrak et al. [21-22,24,28]. However, there was a significant difference in attitude as consultants, junior residents and optometrists have positive attitude whereas ophthalmic assistant and other paramedics have a negative attitude towards COVID-19 but positive attitude were found in doctors, nurses and other paramedics in the study done by Richa et al, Giao et al, and Albarrak et al. [21,24,28]. This might be due to lack of practical awareness regarding COVID-19 infection, which has no fixed guidelines till now.

Regarding practice, junior residents have overall good practice as compared to other participants which was statistically significant $(\mathrm{p}<0.001)$ and as per the study conducted by Saqlain et al. [22] but contradictory with the study by Richa et al., Giao et al., and Albarrak et al. in which position of HCP is associated with good practice [21,24,28]. As ophthalmic residents from various medical colleges and teaching hospitals, besides providing emergency and essential eye care services are also involved in COVID-19 cases management as frontliners. At this time of global health crisis, they are performing their duties very cautiously and with full responsibility as a role model for other paramedics to combat this pandemic.

No significant association was found regarding knowledge among ophthalmic HCP based on their job experience which was in accordance to findings by Richa et al., Saqlain et al and 
Albarrak et al., and Giao et al. [21-22,24,28]. Job experience was significantly associated with attitude score in a study by Richa et al. [21] which is different from present study and studies by Saqlain et al, Giao et al, and Albarrak et al. [22,24,28]. There was no association of job experience with practice in our study but it was found significantly associated in a study done by Richa et al. $(\mathrm{p}=0.013)$ and Saqlain et al. $(\mathrm{p}=0.012)$ [21,22]. This might be due to a lack of active involvement in the management of COVID-19 patients.

Similar to present study, Richa et al. reported significant correlation of practice scores with knowledge score $(r=0.476, p<0.001)$ and attitude scores $(r=0.238, p<0.001)$; and Saqlain et al. reported significant correlation between knowledge-attitude $(\mathrm{r}=0.106$, $\mathrm{p}$-value $=0.030)$, knowledge-practice $(\mathrm{r}=0.142, \mathrm{p}=0.016)$, and attitude-practice $(\mathrm{r}=0.174, \mathrm{p}=0.004)[21,22]$. This finding inferred that ophthalmic HCP with a positive attitude are more interested in seeking knowledge and then put knowledge into practice. This correlation could also be explained by the "Reasoned action theory" which stated, "a person's intention to a specific behavior is a function of their attitude towards that behavior" [29].

Binary logistic regression analysis demonstrated the age of HCP to be a significant determinant of good knowledge $(\mathrm{COR}=0.72,95 \% \mathrm{CI}=0.62-0.82)$, positive attitude $(\mathrm{COR}=0.92,95 \% \mathrm{CI}=0.90-0.94)$ and good practice $(\mathrm{COR}=1.16,95 \% \mathrm{CI}=1.10-1.21)$ which similar to Richa et al and Saqlain et al. [21,22]. Odds of having positive attitude was higher among HCP with job experience of 5-10 years $(\mathrm{OR}=1.838, \mathrm{p}=0.002)$, which was in accordance with the study of Richa et al. [21]. Similarly, higher odds of good practice was seen among junior resident $(\mathrm{OR}=3.846, \mathrm{p}<0.001)$ and $\mathrm{HCP}$ with job experience of 5-10 years $(\mathrm{OR}=0.420, \mathrm{p}=0.010)$ as found in the study by Richa et al and Saqlain et al towards COVID19 pandemic $[21,22]$.

Regression analysis also indicated that experienced health care professionals have good practice in following guidelines recommendations especially wearing a face mask as it is 
evident that the use of personal protective equipment might help reduce the spread of the virus in hospitals and protect others from infection [31]. Patients with SARS-CoV-2 infection may be asymptomatic, and shedding seems to be highest in the earliest stage. Thus, asymptomatic carriers of SARS-CoV-2 may confer a particular risk to ophthalmologists during the examination. Specific factors may place ophthalmologists at increased risk of infection during the examination of patients compared with the risk experienced by clinicians in other disciplines [31].

This study highlighted the less explored area where scarce current literature on COVID-19 was available to identify the current status of ophthalmic HCP knowledge, attitude, and practice; an important aspect in a successful response to an epidemic. The questionnaire was developed by using WHO published materials, guidelines, and recommendations from AAO and NOS, and pre-testing validation which increases the reliability of the current analysis. High response rate as compared to other similar studies and participation from various eye centers across the country which is the representative for ophthalmic HCP. These all constitute the strength of this study. Being an online survey, responses mainly depend upon the honesty and partly affected by recall ability and thus may subject to recall bias, potential sample clustering and statistical errors due to multiple significance testing may limit the generalization (external validity) of the results, non-probability sampling method and those who don't have internet facility, could not get chance to enroll in the study are its limitation.

Though the majority of ophthalmic HCP have good knowledge, they are lacking sufficient positive attitude and satisfactory level of evidence-based practice towards the COVID-19 pandemic. Hence, this study can be taken as a reference during this COVID-19 era to modify existing guidelines; formulate new policies and guidelines for eye care service; and guide concerned authorities for effective implementation of initiatives like motivation, incentives, insurance policy, job security and provision for families of $\mathrm{HCP}$, to combat this battle against 
COVID-19. This study has also highlighted the need to uplift our preparedness by the provision of sustained supply of PPE while augmenting awareness on infection prevention and training programs for control measures.

\section{Supporting information}

S1 data.Questionnaire for participants (DOCX).

S2 dataset (SAV).

\section{Acknowledgment}

We would like to acknowledge all the participants of this study who gave their valuable time for the research, our teachers particularly Prof Badri Prasad Badhu, Prof Poonam Lavaju, Dr. B.G. Shrestha, Dr. Sangeeta Shah and Dr. Santosh Chaudhary, and one of our collegue, Dr. Roshan Dhakal who provided support at every step of the research.

\section{Author's contribution}

Conceptualization: Zahir Ansari

Data curation: Zahir Ansari and Sirjana Adhikari

Formal analysis: Zahir Ansari, Sirjana Adhikari, Sahana Khatoon and Bikram Adhikari

Investigation: Zahir Ansari, Uday Chandra Prakash and Bkiram Adhikari

Methodology: Zahir Ansari, Uday Chandra Prakash and Bikram Adhikari

Project administration: Sahana Khatoon

Resources: Sahana Khatoon

Supervision: Sahana Khatoon

Validation: Zahir Ansari and Bikram Adhikari

Visualization: Bikram Adhikari

Writing - original draft: Zahir Ansari, BD Chaurasiya and Bikram Adhikari

Writing - review \& editing: Zahir Ansari, BD Chaurasiya and Bikram Adhikari 


\section{References}

1. Huang C, Wang Y, Li X, Ren L, Zhao J, Hu Y, et al. Clinical features of patients infected with 2019 novel co. Wuhan, China. Lancet. 2020;395(10223):497-506.https://doi.org/10.1016/S0140-6736(20)30183-5

2. Chen N, Zhou M, Dong X, Qu J, Gong F, Han Y, et al. Epidemiological and clinical characteristics of 99 case coronavirus pneumonia in Wuhan, China: a descriptive study. Lancet. 2020; 395(10223):507-

\section{3.https://doi.org/10.1016/S0140-6736(20)30211-7}

3. Lee KJ.2020 Feb 10.Coronavirus kills Chinese whistleblower ophthalmologist: American Academy of Ophth: announcement.Clinical edication/News/Headline.

4. Parrish RK 2nd, Stewart MW, Duncan Powers SL. Ophthalmologists Are More Than Eye Doctors-In Memori Am J Ophthalmol. 2020;213:A1-A2.https://doi.org/10.1016/j.ajo.2020.02.014 PMID:32169251.

5. Bacherini D, Biagini I, Lenzetti C, Virgili G, Rizzo S. Trends in Molecular Medicine Science and Society Thı Pandemic from an Ophthalmologist's Perspective. Trends in Molecular Medicine. 2020;26(6):529-

531.https://doi.org/10.1016/j.molmed.2020.03.008 PMID:32470381

6. COVID-19 Public Health Emergency of International Concern (PHEIC) Global Research and Innovation Forı Organization, World Health Organization, 12 Feb. 2020[citated April 10 2020].[Internet].Available from: https://www.who.int/publications/m/item/covid-19-public-health-emergency-of-international-concern-(pheic) 
and-innovation-forum

7. World Health Organization.WHO Director-General's opening remarks at the media briefing on COVID-19.W Director/General/Speech;11march 2020[citated April 10 2020].[Internet]. Available from: https://www.who.int/dg/speeches/detail/who-director-general-s-opening-remarks-at-the-media-briefing-on-co march-2020

8. Worldometer. Coronavirus Cases.Worldometer 2020[citated April 10 2020].[Internet].Availablefrom:https://www.worldometers.info/coronavirus/?utm_campaign=homeAdvegas1' $\underline{0 \%}$.

9. ACAPS Briefing note - Nepal: COVID-19 \& the return of migrants. ACAPS Start Network; 12 June 2020[cit 2020].[Internet]. Available from: https://reliefweb.int/report/nepal/acaps-briefing-note-nepal-covid-19-return$\underline{2020}$

10. Bastola A, Sah R, Rodriguez-Morales AJ, Lal BK, Jha R, Ojha HC, et al. The first 2019 novel coronavirus ca: Infect Dis. 2020;20((3)):279-280.https://doi.org/10.1016/S1473-3099(20)30067-0

11. Gharebaghi R, Moshirfar M, Desuatels J, Parvizi M, Daryabari S-H, Heidary F, COVID-19: Preliminary Clin Ophthalmology Practices. Med Hypothesis Discov Innov Ophthalmol. 9(2):149-158.

12. Xia J, Tong J, Liu M, Shen Y GD. Evaluation of coronavirus in tears and conjunctival secretions of patients v infection. J Med Virol 2020. 2020;92(6):589-594. https://doi.org/10.1002/jmv.25725 PMID:32100876

13. Hoe Gan W, Wah Lim J, Koh D. Preventing intra-hospital infection and transmission of COVID-19 in health، 
[published online ahead of print, 2020 Mar 24]. Saf Health Work. 2020;11(2):241-

243.https://doi.org/10.1016/j.shaw.2020.03.001

14. Nemati M, Ebrahimi B, Nemati F. Assessment of Iranian nurses' knowledge and anxiety toward COVID-19 d outbreak in Iran. Archives of Clinical and Infectious Diseases.March 2020. https://doi.org/10.5812/archcid.10

15. Omrani AS, Shalhoub S. Middle East respiratory syndrome coronavirus (MERS-CoV): what lessons can we 1 Infect. 2015;91(3):188-196.https://doi.org/10.1016/j.jhin.2015.08.002 PMID:26452615

16. Ahmed MA, Rehab HE, Mahdi AA ME. Knowledge and attitudes towards Middle East respiratory syndrome(MERS-CoV) among health care workers in south-western Saudi Arabia. East Mediterr Health J. 2019;25(x): xxx.https://doi.org/10.26719/emhj.19.079 PMID:32338362

17. World Health Organization.Question \& Answer on coronaviruses (COVID-19). [citated April 10 2020].[Interr from: https://www.who.int/emergencies/diseases/novel-coronavirus-2019/question-and-answers-hub/q-a-deta: coronaviruses

18. Nepal Opthalmic Society. COVID-19 Ophthalmic Practical Guidelines. 2020 April.[citated May 15 2020].[In from: http://www.nos.com.np/covid-19/nos-covid-19-practice-guidelines.pdf

19. American Academy of Ophthalmology. Important coronavirus updates for ophthalmologists. [citated May 15 2020].[Internet].Available from: https://www.aao.org/headline/alert-important-coronavirus-context

20. Asraf H, Garima T, Singh BM, Ram R, Tripti RP. Knowledge, attitudes, and practices towards COVID-19 an Residents $\square$ :A quick online cross-sectional survey.Asian Journal Medical Sciences 
21. Richa Nepal, Sapkota K, Adhikari K, Paudel P, Adhikari B, Paudyal N, et al. Knowledge , attitude and practic COVID-19 among healthcare workers in Chitwan, Nepal.[preprint BMC infectious disease 2020];1-23.

22. Saqlain M, Munir MM, Rehman SU, Gulzar A, Naz S, Ahmed Z, et al.Knowledge, attitude, practice and perc among healthcare professionals regarding COVID-19: A Cross-sectional survey from Pakistan. J Hosp Infect. 423.https://doi.org/10.1016/j.jhin.2020.05.007 PMID:32437822

23. Zhang M, Zhou M, Tang F, Wang Y, Nie H, Zhang L, et al.Knowledge, attitude, and practice regarding COV healthcare workers in Henan, China. J Hosp Infect. 2020;105(2):183-187.https://doi.org/10.1016/j.jhin.2020.C PMID:32278701

24. Chi H, City M, Giao H, Thi N, Han N, Khanh T Van, et al. Knowledge and attitude toward COVID-19 amon workers at District 2 Hospital, Ho Chi Minh City. Asian Pac J Trop Med 2020; 13(6): 260-265.

25. World Health Organization. Solidarity-clinical-trial-for-covid-19-treatments 2020[citated May 10 2020].[Inte from: https://www.who.int/emergencies/diseases/novel-coronavirus-2019/global-research-on-novel-coronavir $\underline{\text { ncov/solidarity-clinical-trial-for-covid-19-treatments }}$

26. Amirian ES, Levy JK. Current knowledge about the antivirals remdesivir (GS-5734) and GS-441524 as thera] coronaviruses. One Health. 2020;100128.

https://doi.org/10.1016/j.onehlt.2020.100128 PMID:32258351

27. Iliyasu G, Ogoina D, Otu AA, Dayyab FM, Ebenso B, Otokpa D, et al.A Multi-Site Knowledge Attitude and ] Ebola Virus Disease in Nigeria. PLoS ONE 2015 10(8): e0135955.https://doi.org/10.1371/journal.pone.0135؟ 
PMID:26317535

28. Albarrak AI, Mohammed R, Elayan A Al, Fawaz F Al, Masry M Al, Shammari M Al, et al. Middle East Resf (MERS): Comparing the knowledge, attitude and practices of different health care workers. Journal of Infecti Health.2019;617:6-13.https://doi.org/10.1016/j.jiph.2019.06.029

29. Fisher WA, Fisher JD, Rye BJ. Understanding and Promoting AIDS-Preventive Behavior $\square$ : Insights From th Reasoned Action. 1995;14(3):255-64.https://doi.org/10.1037/0278-6133.14.3.255 PMID:7641667

30. Song W, Fan M CBJ. Feng S, Shen C, Xia N.Rational use of face masks in the COVID-19 pandemic. Lancet 2020;2:2019-20.

31. Wong Y, Wong EY, Mehta J, Park KH, Fung AT, Franzco M, et al. Preparedness among Ophthalmologists: I Beyond the COVID-19 Pandemic. Ophthalmology. 2020;127(5): 569-72.https://doi.org/10.1016/j.ophtha.202

PMID:32327128 
medRxiv preprint doi: https://doi.org/10.1101/2020.08.13.20174052; this version posted August 14, 2020. The copyright holder for this preprint (which was not certified by peer review) is the author/funder, who has granted medRxiv a license to display the preprint in perpetuity.

It is made available under a CC-BY-NC-ND 4.0 International license
. 
medRxiv preprint doi: https://doi.org/10.1101/2020.08.13.20174052; this version posted August 14, 2020. The copyright holder for this preprint (which was not certified by peer review) is the author/funder, who has granted medRxiv a license to display the preprint in perpetuity.

It is made available under a CC-BY-NC-ND 4.0 International license. 
medRxiv preprint doi: https://doi.org/10.1101/2020.08.13.20174052; this version posted August 14, 2020. The copyright holder for this preprint (which was not certified by peer review) is the author/funder, who has granted medRxiv a license to display the preprint in perpetuity.

It is made available under a CC-BY-NC-ND 4.0 International license. Remdesivir-FDA issued an emergency authorization for the treatment of
suspected or laboratory-confirmed COVID-19.

The risk of irreversible maculopathy at these higher doses of chloroquinine and hydroxycholoroquine for short periods of time is unknown.

Examinig and treating(office based procedures, emergency surgeries)
ophthalmic HCPS should wear PPE.

Office based procedures(tarsorrhaphy,intravitreal injection), use of N95 masks(if

융 adequate supply)/surgical mask and eye protection are recommended.

Using slit lamp barriers/breath shields provides added protection against virus.

SARS-CoV-2 is susceptible to the same alcohol and bleach-based disinfectants that commonly use to disinfect ophthalmic instruments and office furniture.

Acute conjuctivitis can be an early features of COVID-19.

Ophthalmogists and its allied health care professionals at more risk. Apart from transmission by respiratory droplets, hand to eye contact,
contaminated euipments, can also transmit through tears and ocular secretions.

COVID-19 is a viral infection(SARS-CoV-2)
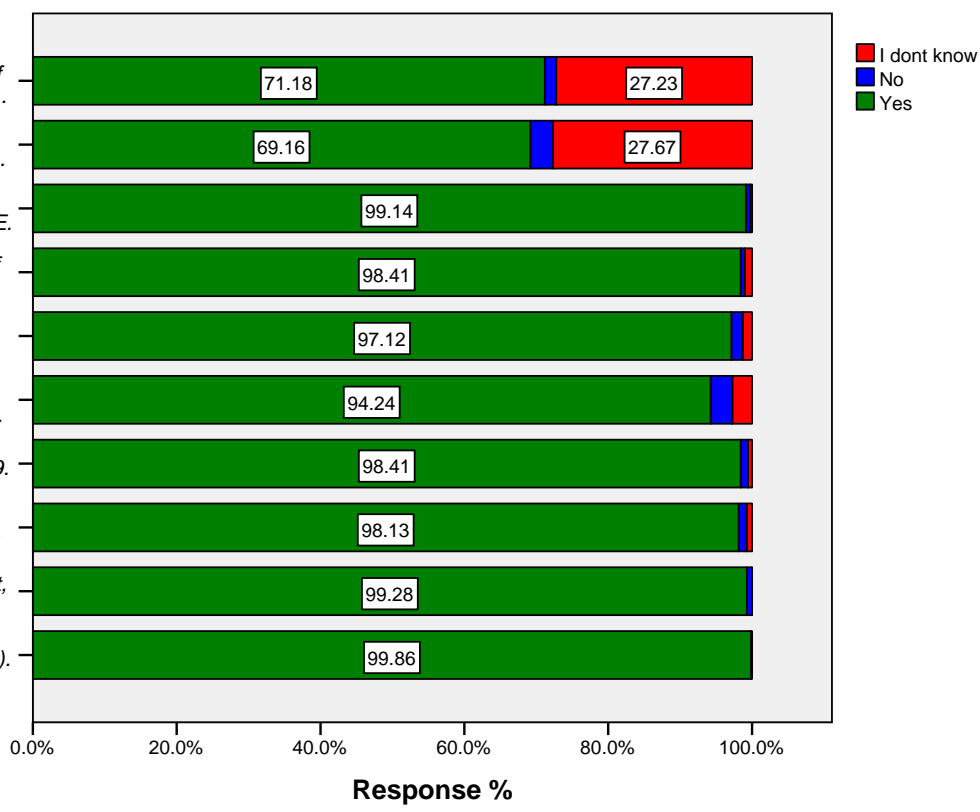
medRxiv preprint doi: https://doi.org/10.1101/2020.08.13.20174052; this version posted August 14, 2020. The copyright holder for this preprint (which was not certified by peer review) is the author/funder, who has granted medRxiv a license to display the preprint in perpetuity.

\section{It is made available under a CC-BY-NC-ND 4.0 International license .}

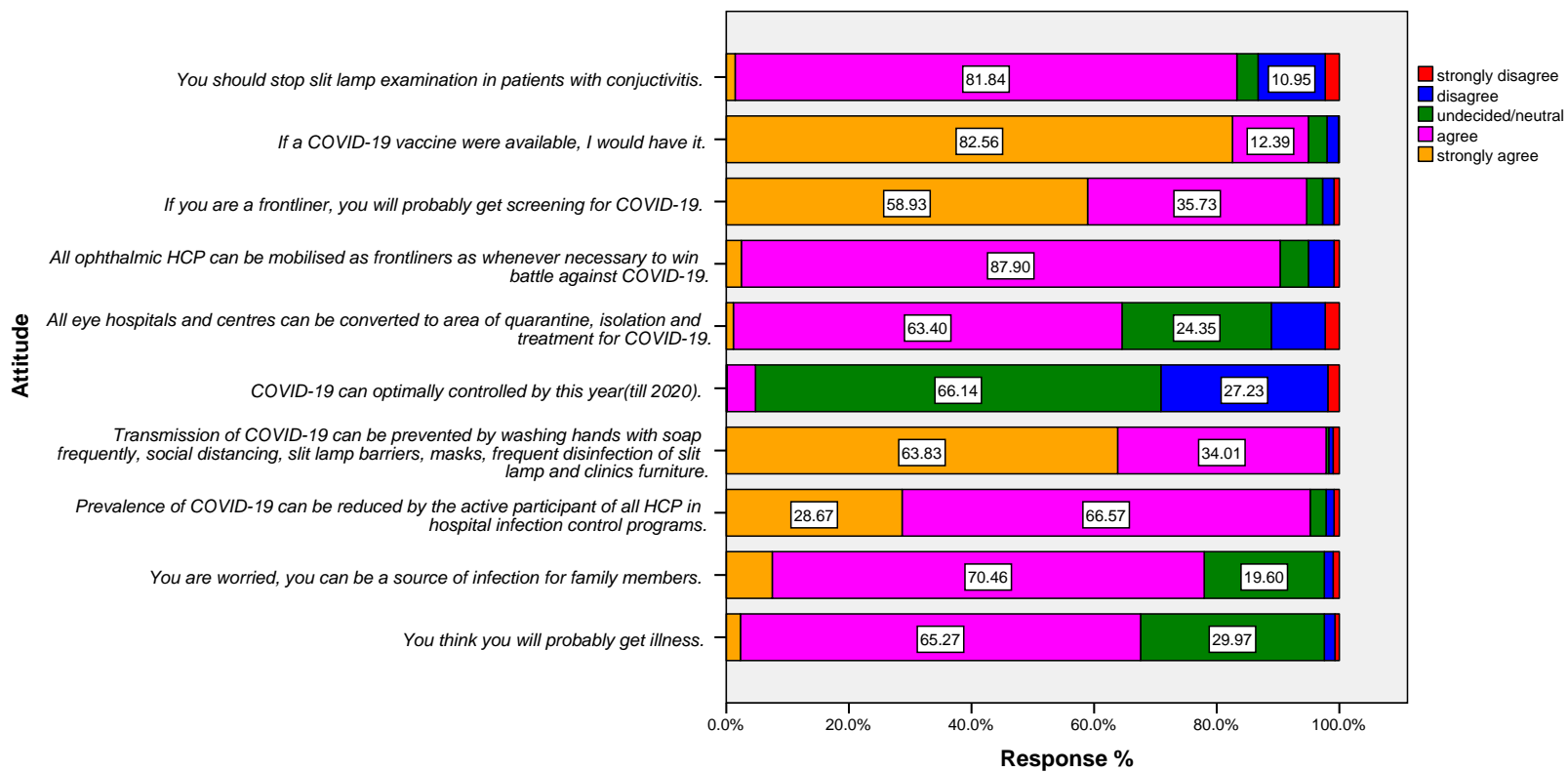


medRxiv preprint doi: https://doi.org/10.1101/2020.08.13.20174052; this version posted August 14, 2020. The copyright holder for this preprint (which was not certified by peer review) is the author/funder, who has granted medRxiv a license to display the preprint in perpetuity.

\section{It is made available under a CC-BY-NC-ND 4.0 International license .}

ষ্ঠ

Do you avoiding routine ocular surgeries and providing only emergency surgical

Are you being qurantine, isolated or tested for COVID-19?

Are you collecting or involve in collecting nasopharyngeal swab procedure?

Do you participate in training programmes of COVID-19?

Are you working as frontliners in this COVID-19 crisis?

Do you avoiding routine ocular surgeries and providing only emergency surgical
care with adequate PPE as recommended?

Are you using telemedicine(videos/helpline mobile number based) for continuing regular eye services?

Do you avoiding direct fundoscopy instead performing indirect if required?

Are you using simple surgical gown, masks, and disposable gloves for every routine slit examination

Do slit lamps are being attached with barriers/breath shields and more aggressively disinfected with alcohol?

Are you following strict social distancing inside clinics as reccomended by

Are you screening each patient for COVID-19 and whether mask wearing or not, before registrating for clinics?

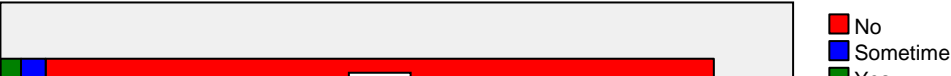

\subsection{6}

Yes

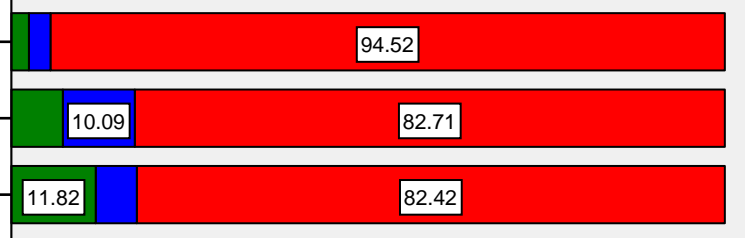

\section{$-10$}

\begin{tabular}{|l|l|l|}
\hline 57.49 & 22.91 & 19.60 \\
\hline
\end{tabular}

\begin{tabular}{l|r}
13.40 & 79.68
\end{tabular}
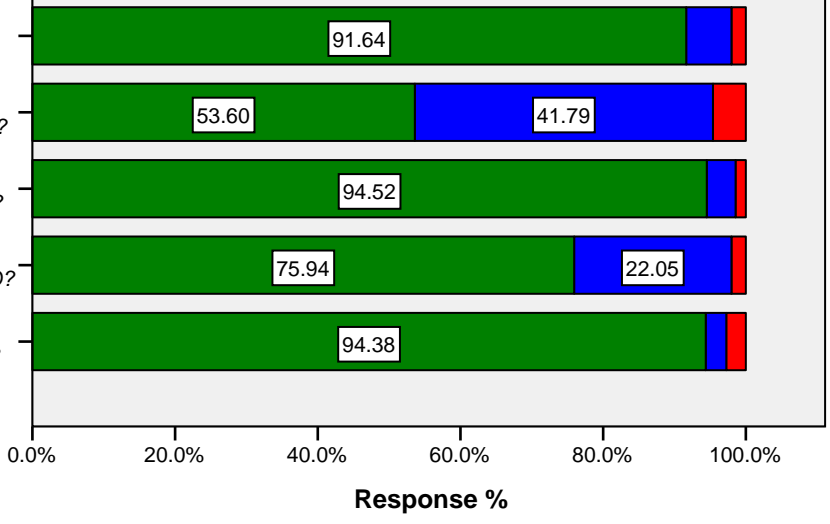


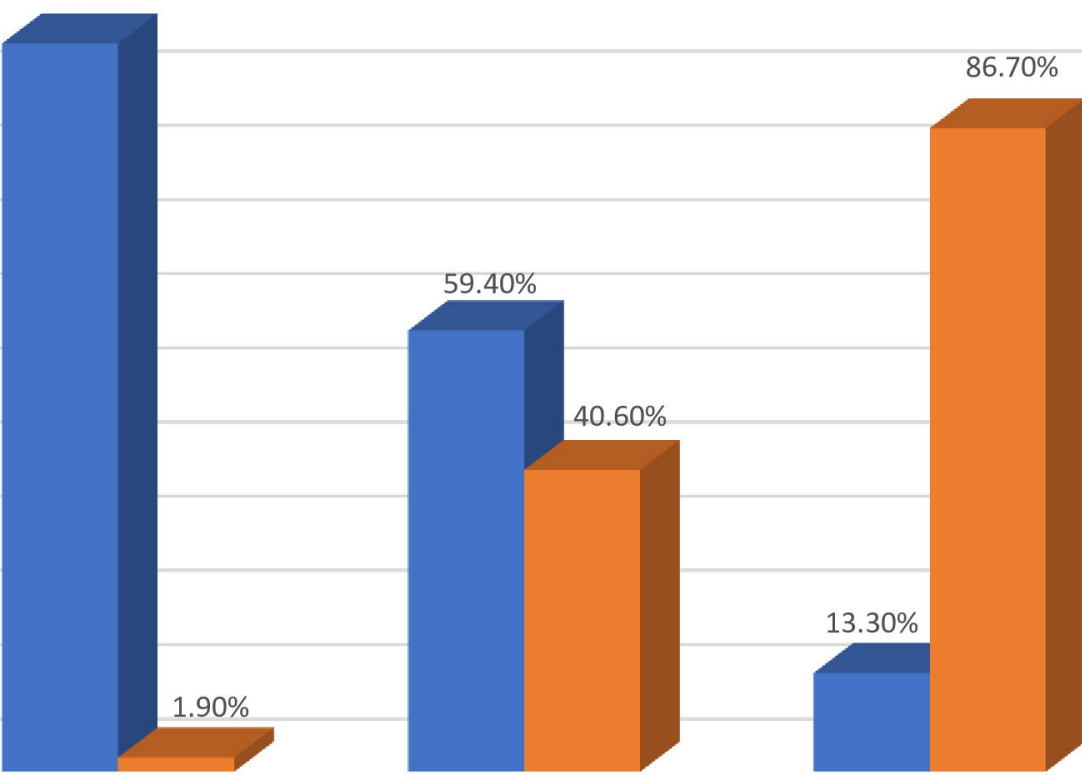

Knowledge

Attitude

Practice 